\title{
Pengaruh Konsep Diri dan Self Disclosure Terhadap Kemampuan Komunikasi Interpersonal Mahasiswa
}

\author{
Karin Juliana, Rezi Erdiansyah \\ karinjuliana77@gmail.com,rezie@fikom.untar.ac.id \\ Fakultas Ilmu Komunikasi Universitas Tarumanagara
}

\begin{abstract}
This study aims to determine the effect of self concept and self disclosure on students' interpersonal communication skills. The subjects on this research is 149 students spread across 24 campuses. Data analysis using SEM with the application of LISREL 8.70. Based on the results of the study found that there is a significant effect between self concept and self disclosure on students' interpersonal communication skills. From the two independent variables it turns out that the concept of self concept has more influence than self disclosure on students' interpersonal communication skills. Thus it can be concluded that interpersonal communication is influenced by self concept and self disclosure.
\end{abstract}

Keywords: interpersonal communication, self concept, self disclosure, students.

\begin{abstract}
Abstrak
Penelitian ini bertujuan untuk mengetahui pengaruh konsep diri dan self disclosure terhadap kemampuan komunikasi interpersonal mahasiswa. Jumlah responden yang digunakan dalam penelitian ini sebanyak 149 responden yang tersebar di 24 kampus. Analisis data menggunakan SEM dengan aplikasi LISREL 8.70. Berdasarkan hasil penelitian ditemukan bahwa terdapat pengaruh yang signifikan antara konsep diri dan self disclosure terhadap kemampuan komunikasi interpersonal mahasiswa. Dari kedua variabel independen ternyata variabel konsep diri memiliki pengaruh yang lebih dibandingkan self disclosure terhadap komunikasi interpersonal mahasiswa. Dengan demikian, dapat disimpulkan bahwa komunikasi interpersonal dipengaruhi oleh konsep diri dan self disclosure.
\end{abstract}

Kata kunci: komunikasi interpersonal, konsep diri, mahasiswa, self disclosure.

\section{Pendahuluan}

Manusia dalam ilmu sosial disebut juga makhluk sosial, artinya tidak dapat hidup sendiri karena membutuhkan orang lain yang ada disekitarnya. Dalam kehidupan sehari-hari, manusia perlu untuk melakukan interaksi dengan sesamanya. Menurut Tri dkk (2016), ruang lingkup komunikasi pada diri seseorang meliputi komunikasi interpersonal, komunikasi intrapersonal, dan hubungan yang mengandung unsur partisipasi. Yang menjadi dasar untuk melakukan interaksi dengan orang lain adalah komunikasi interpersonal. Menurut Devito (2013), komunikasi interpersonal adalah "interpersonal communication is communication that takes place between people who are in some way connected." Dari definisi tersebut dapat diartikan bahwa komunikasi interpersonal merupakan komunikasi yang dilakukan secara dua arah atau lebih. Komunikasi interpersonal juga dipengaruhi oleh beberapa faktor yaitu persepsi interpersonal, konsep diri, atraksi interpersonal, dan hubungan interpersonal (Yohana, 
2014). Salah satu faktor yang akan diteliti dalam penelitian ini adalah konsep diri yang mempengaruhi mahasiswa dalam berkomunikasi dengan orang lain.

Menurut Andayani (2010), konsep diri adalah pandangan individu mengenai diri yang diinginkannya. Konsep diri merupakan faktor penting yang harus dimiliki seseorang untuk melakukan interaksi. Menurut Yohana (2014), mahasiswa yang memiliki konsep diri secara positif akan mempengaruhi komunikasi interpersonal mahasiwa. Hal ini disebabkan karena mahasiswa merupakan agen perubahan yang memiliki hubungan langsung dengan masyarakat luas, sehingga kebutuhan akan komunikasi selalu ada. Konsep diri juga merupakan peranan penting dalam komunikasi interpersonal.Selain konsep diri, untuk dapat berinteraksi dengan orang lain, mahasiswa membutuhkan keterbukaan diri dengan orang lain. Menurut Devito (2011, dalam Massie 2018) keterbukaan diri atau dalam bahasa inggris disebut self disclosure merupakan salah satu tipe komunikasi dimana informasi tentang diri yang biasa dirahasiakan diberitahukan kepada orang lain.

Menurut Lestari (2016), untuk dapat melakukan interaksi dengan orang lain, sangat membutuhkan keterbukaan diri atau self disclosure dengan orang lain. Self disclosure merupakan salah satu keterampilan komunikasi yang sangat penting untuk mahasiswa saat menjalin hubungan dan interaksi dengan orang lain. Dalam keterbukaan diri juga terdapat beberapa dimensi, yaitu jumlah informasi yang diungkapkan, dalamnya suatu pengungkapan saat seseorang melakukan keterbukaan diri, sikap dasar positif dan negatif yang menyangkut tentang, bagaimana seorang individu mengungkapkan dirinya, waktu pengungkapan diri, serta lawan bicara pada saat mahasiswa melakukan keterbukaan diri/pengungkapan diri mengenai hal-hal yang ada dalam dirinya. Menurut Tri et al. (2016) bahwa semakin besar nilai self disclosure, maka semakin meningkat pula nilai komunikasi interpersonal seseorang. Menurut Milliard J Bienvu (1987, dalam Tri et al 2016) dikatakan bahwa adanya self disclosure pada diri seseorang, maka akan dapat mempermudah seseorang untuk berkomunikasi dengan orang lain secara bebas dan terus terang. Mahasiswa memiliki kecenderungan untuk berinteraksi dengan sesamanya dengan adanya keterbukaan diri yang timbul oleh kepercayaan.

Rumusan masalah yang akan dibahas dalam penelitian ini yaitu apakah konsep diri berpengaruh secara signifikan terhadap kemampuan komunikasi interpersonal mahasiswa? apakah self disclosure berpengaruh secara signifikan terhadap kemampuan komunikasi interpersonal mahasiswa? Dari uraian di atas dapat diketahui bahwa tujuan dari penelitian ini adalah untuk mengetahui seberapa besar pengaruh konsep diri terhadap kemampuan komunikasi interpersonal mahasiswa serta untuk mengetahui seberapa besar pengaruh self disclosure terhadap kemampuan komunikasi interpersonal mahasiswa.

\section{Metode Penelitian}

Dalam penelitian ini peneliti menggunakan metode penelitian kuantitatif. Metode penelitian kuantitatif merupakan metode penelitian yang digunakan untuk meneliti pada populasi atau sampel tertentu, pengumpulan data menggunakan instrumen penelitian, analisis data yang bersifat statistik dan bertujuan untuk menguji hipotesis-hipotesis (Siregar 2013, 8; Sugiyono 2017)

Survei penelitian ini menggunakan 26 indikator pernyataan yang disusun berdasarkan dimensi yang membentuk dan mempengaruhi masing-masing variabel. Terdapat lima dimensi yang mempengaruhi dan membentuk komunikasi interpersonal 
menurut Devito (2004, dalam Yohana 2014). Variabel X1 yaitu konsep diri, dibentuk oleh tiga dimensi menurut Calhoun dan Acocelia (1990, Hadi dkk 2014). Variabel X2 dibentuk oleh lima dimensi menurut Pearson (dalam Lestari 2016).

Penulis menggunakan skala likert. Menurut Sugiyono (2017), skala likert digunakan untuk mengukur sikap, pendapat, dan persepsi seseorang atau sekelompok orang tentang fenomena sosial. Dengan menggunakan skala ini maka semua variabel yang ada, akan diukur dan diubah menjadi indikator variabel dan indikator variabel tersebut digunakan untuk menyusun item instrumen berupa pernyataan. Terdapat lima poin dalam skala likert. Penulis menggunakan program statisical product and service solutions (SPSS). Program ini digunakan untuk mendapatkan data mengenai karakteristik responden, uji validitas, dan uji realibilitas. Hasil uji analisis dalam penelitian ini guna untuk melihat apakah hasil hipotesis diterima atau tidak. Pengelolahan data dalam penelitian ini menggunakan software LISREL 8.70 dari program structural equation model (SEM).

\section{Hasil Temuan dan Diskusi}

\section{Karakteristik Responden}

Responden untuk penelitian ini berjumlah 149 orang. Dengan jumlah responden laki-laki dalam penelitian ini sebanyak 54 orang atau dengan persentase $36,2 \%$, dan jumlah responden perempuan dalam penelitian ini sebanyak 95 orang atau dengan persentase $63.8 \%$. Usia responden pada penelitian ini berusia 18-22 tahun. Dengan responden yang berumur 18 tahun sebanyak 10 orang atau dengan persentase $6.7 \%$, responden yang berumur 19 tahun sebanyak 10 orang atau dengan persentase $12.8 \%$, responden yang berumur 20 tahun sebanyak 47 orang atau dengan persentase $31.5 \%$, responden yang berumur 21 tahun sebanyak 46 orang atau dengan persentase $30.9 \%$, responden yang berumur 22 tahun sebanyak 20 orang atau dengan persentase $13.4 \%$, serta terdapat responden yang berumur diatas 22 tahun sebanyak 7 orang orang atau dengan persentase $4.7 \%$.

\section{Uji Validitas}

Menurut Nisfiannoor (2013), validitas merupakan suatu uji dalam penelitian yang digunakan untuk mengukur sejauh mana hasil penelitian mencerminkan atau sesuai dengan keadaan yang sebenarnya. Dalam hal ini, untuk mengukur valid atau tidaknya suatu penelitian, maka digunakan patokan 0.2 dan patokan ini dibandingkan dengan angka yang berada pada kolom Corrected Item-Total Correlation. Jika angka korelasi berada dibawah 0.2 , maka dinyatakan gugur. Namun jika angka korelasi di atas 0,2 maka dinyatakan valid.

Tabel 1. Hasil Uji Validitas

\begin{tabular}{clc}
\hline \multirow{2}{*}{ Variabel } & \multicolumn{1}{c}{ Butir Indikator } & $\begin{array}{c}\text { Corrected Item } \\
\text { Total } \\
\text { Correlation }\end{array}$ \\
\hline \multirow{2}{*}{ Konsep Diri } & Saya mengenal diri saya dengan baik. & 0,561 \\
\cline { 2 - 3 } & $\begin{array}{l}\text { Saya mengenal lingkungan di sekitar saya } \\
\text { dengan baik. }\end{array}$ & 0,559
\end{tabular}




\begin{tabular}{|c|c|c|}
\hline & $\begin{array}{l}\text { Saya memiliki gambaran diri yang ideal untuk } \\
\text { diri saya }\end{array}$ & 0,522 \\
\hline & $\begin{array}{l}\text { Saya berharap gambaran diri ideal saya dapat } \\
\text { tercapai di masa depan. }\end{array}$ & 0,333 \\
\hline & Saya memiliki penilaian terhadap diri saya. & 0,388 \\
\hline & $\begin{array}{l}\text { Saya memiliki penilaian yang baik untuk diri } \\
\text { saya. }\end{array}$ & 0,363 \\
\hline \multirow{10}{*}{ Self Disclosure } & $\begin{array}{l}\text { Saya selalu bersikap terbuka terhadap orang } \\
\text { lain. }\end{array}$ & 0,634 \\
\hline & $\begin{array}{l}\text { Saya biasa mengungkapkan informasi-informasi } \\
\text { tentang diri saya. }\end{array}$ & 0,727 \\
\hline & $\begin{array}{l}\text { Saya biasa terbuka mengenai hal-hal positif } \\
\text { yang terjadi dalam diri saya. }\end{array}$ & 0,430 \\
\hline & $\begin{array}{l}\text { Saya biasa terbuka mengenai hal-hal negatif } \\
\text { yang terjadi dalam diri saya. }\end{array}$ & 0,553 \\
\hline & $\begin{array}{l}\text { Saya melakukan keterbukaan diri secara } \\
\text { mendalam kepada orang lain. }\end{array}$ & 0,661 \\
\hline & $\begin{array}{l}\text { Saya membatasi diri/ tidak terlalu terbuka } \\
\text { kepada orang lain. }\end{array}$ & 0,334 \\
\hline & $\begin{array}{l}\text { Saya selalu siap kapanpun untuk terbuka kepada } \\
\text { orang lain. }\end{array}$ & 0,565 \\
\hline & Saya mampu terbuka dalam kondisi apapun. & 0,597 \\
\hline & $\begin{array}{l}\text { Saya tidak memilih-milih lawan bicara dalam } \\
\text { melakukan keterbukaan diri. }\end{array}$ & 0,476 \\
\hline & $\begin{array}{l}\text { Saya memiliki kedekatan dengan lawan bicara } \\
\text { pada saat melakukan keterbukaan diri. }\end{array}$ & 0,258 \\
\hline \multirow{7}{*}{$\begin{array}{l}\text { Komunikasi } \\
\text { Interpersonal }\end{array}$} & $\begin{array}{l}\text { Saya bersedia untuk saling terbuka dengan } \\
\text { orang lain. }\end{array}$ & 0,388 \\
\hline & $\begin{array}{l}\text { Saya bersikap jujur saat berinteraksi dengan } \\
\text { orang lain. }\end{array}$ & 0,458 \\
\hline & $\begin{array}{l}\text { Saya mampu merasakan apa yang dialami oleh } \\
\text { orang lain. }\end{array}$ & 0,442 \\
\hline & $\begin{array}{l}\text { Saya bersedia menolong orang lain untuk } \\
\text { mengurangi masalah yang dihadapinya. }\end{array}$ & 0,423 \\
\hline & $\begin{array}{l}\text { Saya selalu mendengarkan saat orang lain } \\
\text { berbicara. }\end{array}$ & 0,441 \\
\hline & $\begin{array}{l}\text { Saya selalu memberikan pendapat atau respon } \\
\text { untuk lawan bicara saya. }\end{array}$ & 0,360 \\
\hline & $\begin{array}{l}\text { Saya selalu bersikap positif atas apa yang terjadi } \\
\text { pada diri saya. }\end{array}$ & 0,470 \\
\hline
\end{tabular}


Sumber: Data Pengelolaan dengan SPSS 23

Dari uji validitas tersebut diketahui bahwa pernyataan dari seluruh variabel adalah valid. Dapat dibuktikan dari hasil korelasi per butir indikator diatas 0,2.

\section{Uji Realibilitas}

Menurut Siregar (2013), reliabilitas adalah uji yang dilakukan untuk mengetahui sejauh mana hasil pengukur tetap konsisten, apabila dilakukan pengukuran dua kali atau lebih terhadap gejala yang sama dengan menggunakan alat pengukur yang sama pula.Uji realibilitas dalam penelitian ini menggunakan program SPSS menunjukkan bahwa dengan nilai Cronbach's Alpha masing-masing variabel lebih besar dari 0,6, ini berarti realibilitas tergolong baik.

Tabel 2. Hasil Uji Realibilitas

\begin{tabular}{lcc}
\hline \multicolumn{1}{c}{ Variabel } & Nilai Cronbach's Alpha & Keterangan \\
\hline Konsep Diri & 0.715 & Reliabel \\
\hline Self Disclosure & 0.834 & Reliabel \\
\hline Komunikasi Interpersonal & 0.771 & Reliabel \\
\hline
\end{tabular}

Sumber: Data Pengelolaan dengan SPSS 23

Dari data tabel di atas dapat disimpulkan bahwa variabel konsep diri, self disclosure, dan komunikasi interpersonal yang digunakan pada penelitian ini dinyatakan reliable. Hal ini dapat dibuktikan dengan nilai Cronbach's Alpha masingmasing variabel lebih besar dari 0,6. Konsep diri memiliki nilai Cronbach's Alpha sebesar 0,715. Self disclosure memiliki nilai Cronbach's Alpha sebesar 0,834. Komunikasi Interpersonal memiliki nilai Cronbach's Alpha sebesar 0,771.

\section{Uji Hipotesis}

Analisis data pada penelitian ini diperoleh dari hasil pengujian hipotesis penelitian. Menurut Sugiyono (2017), hipotesis merupakan jawaban sementara terhadap rumusan masalah penelitian, dimana rumusan penelitian telat dinyatakan dalam bentuk kalimat pertanyaan/pernyataan. Hipotesis merupakan jawaban yang bersifat sementara, dan perlu diuji secara empiris, tentang hubungan antar variabel yang dirumuskan dalam model penelitian (Suryadi dkk, 2019). 
Tabel 3. Uji Hipotesis dengan LISREL

\begin{tabular}{|c|c|c|c|c|c|}
\hline Hipotesis & Path & $\begin{array}{l}\text { Standarized } \\
\text { Solution }\end{array}$ & T-Values & T Tabel & Result \\
\hline H1 & $\begin{array}{l}\text { Konsep diri } \\
\text { Komunikasi } \\
\text { Interpersonal }\end{array}$ & 0.56 & 4.46 & 1.96 & Supported \\
\hline $\mathrm{H} 2$ & $\begin{array}{l}\text { Self disclosure } \\
\text { Komunikasi } \\
\text { Interpersonal }\end{array}$ & 0.46 & 4.14 & 1.96 & Supported \\
\hline
\end{tabular}

Sumber: Data primer, diolah dengan SPSS 15.0

Berdasarkan data, dapat diketahui bahwa Tvalues $=4.46$, dengan nilai Standardized Solution $(\beta)=0,56$. Karena nilai Tvalues $>$ dari nilai $\mathrm{T}$ tabel, $t$ values $=$ $4.46>\mathrm{t}$ tabel $=1,96$ atau dapat diartikan dengan nilai $\mathrm{t}$ value lebih besar dari nilai $\mathrm{t}$ tabel, maka H0 ditolak dan $\mathrm{H} 1$ diterima. Oleh karena itu berdasarkan data diatas, dapat disimpulkan bahwa konsep diri memiliki pengaruh yang positif dan signifikan terhadap kemampuan komunikasi interpersonal mahasiswa. Kemudian self disclosure juga berpengaruh positif dan signifikan terhadap kemampuan komunikasi interpersonal mahasiswa, hal ini dapat dibuktikan bahwa self disclosure memiliki nilai $T$ value $=3.72$, dengan nilai Standardized Solution $(\beta)=0,44$. Karena nilai $T$ value $>$ $\mathrm{T}$ tabel, $t$ value $=3.72>\mathrm{t}$ tabel $=1,96$ atau dapat diartikan dengan nilai $\mathrm{t}$ value lebih besar dari nilai t tabel, maka $\mathrm{H} 0$ ditolak dan $\mathrm{H} 2$ diterima. Berdasarkan penelitian sebelumnya yang dilakukan oleh Corry Yohana (2014), pada penelitian yang berjudul "Hubungan Antara Konsep Diri dengan Komunikasi Interpersonal Pada Mahasiswa Pendidikan Tata Niaga Fakultas Ekonomi Universitas Negeri Jakarta" mendapatkan hasil yang positif antara konsep diri terhadap komunikasi interpersonal mahasiswa.

\section{Simpulan}

Berdasarkan hasil dari penelitian dan hasil dari pembahasan ini, maka dapat ditarik kesimpulan dari penelitian ini sebagai berikut.

a. Konsep diri berpengaruh positif dan signifikan terhadap komunikasi interpersonal

b. Self disclosure berpengaruh positif dan signifikan terhadap komunikasi interpersonal

c. Berdasarkan penelitian yang telah dilakukan oleh penulis, diketahui bahwa variabel yang paling berpengaruh terhadap komunikasi interpersonal mahasiswa adalah konsep diri. Konsep diri terdiri dari beberapa dimensi yaitu dimensi pengetahuan, pengharapan, dan penilaian. Indikator yang paling 
berpengaruh terdapat pada dimensi pengetahuan. Pengetahuan akan diri sendiri dan lingkungan sekitar sangat berpengaruh untuk membentuk konsep diri yang positif seorang mahasiswa.

d. Keterbukaan diri atau self disclosure juga merupakan salah satu variabel yang berpengaruh namun nilainya lebih rendah jika dibandingkan dengan konsep diri.

\section{Ucapan Terima Kasih}

Penelitian ini dapat terlaksana karena bantuan dan dukungan dari banyak pihak. Oleh sebab itu, peneliti ingin menyampaikan rasa terima kasih yang sebesarbesarnya kepada keluarga dan semua pihak yang ikut terlibat dan telah membantu peneliti selama proses penelitian ini berlangsung.

\section{Daftar Pustaka}

Andayani, T. R. (2010). Penyesuaian Sosial Siswa Akselerasi Ditinjau Dari Konsep Diri dan Membuka Diri. Jurnal Pendidikan dan Kebudayaan, 16, 13-20.

Ardiyanti, A. S. (2018). Self disclosure melalui Media Sosial Instagram (Studi Kasus pada Anggota Galeri Quote). Nyimak Journal of Communication, 2, 81=94.

Budiningsih, Y. P. (2014). Konsep Diri Akademik Mahasiswa Penerima Beasiswa Bidik Misi Jurusan Psikologi Universitas Negeri Semarang. Educational Psychology Journal, 3, 26-31.

Edi Suryadi, D. D. (2019). Metode Penelitian Kuantitatif Dengan Pendekatan Kuantitatif. Bandung: PT. Remaja Rosdakarya.

Lestari, Septi Sukma (2016). Hubungan Keterbukaan Diri Dengan Penyesuaian Diri Mahasiswa Baru di Yogyakarta. Jurnal Bimbingan dan Konseling, 3, 1-17.

Liliweri, A. (2015). Interpersonal Communication. Jakarta: Kencana Prenamedia. Martono, N. (2012). Metode Penelitian Kuantitatif. Jakarta: PT.Grafindo Persada.

Massie, Gisela Winny., Susanto, Eko Harry. (2018). Penyikapan Diri Kaum Lesbian Melalui Media Baru Facebook. Koneksi, 372.

Nisfianoor. (2013). Pendekatan Statistika Modern. Jakarta: Universitas Trisakti.

Rohim, S. (2016). Teori Komunikasi. Jakarta: Rineka Cipta.

Siregar, S. (2013). Metode Penelitian Kuantitatif. Jakarta: PT. Fajar Interpratama Mandiri.

Sugiyono. (2016). Metode Penelitian Kuantitatif, Kualitatif, dan R\&D. Bandung: Alfabeta.

Sugiyono. (2017). Metode Penelitian Kuantitatif. Bandung: Alfabeta.

Suryabrata, S. (2015). Metode Penelitian. Jakarta: Rajawali Pers.

Tri, Anisya., Pamula, Ario., Effendi, Citra Kusuma., Setiawan, Didik., Manalu, Fristamia. (2016). Hubungan Antara Self Disclosure Dengan Komunikasi Interpersonal Mahasiswa yang Menggunakan Media Sosial LINE. Proisiding Konseling Nasional Peneliti Muda Psikologi Indonesia, 1, 79-84.

Yohana, Corry. (2014). Hubungan Antara Konsep Diri Dengan Komunikasi Interpersonal Pada Mahasiswa Pendidikan Tata Niaga Fakultas Ekonomi Universitas Negeri Jakarta. EconoSains, 12, 1-13. 